\title{
Studi Epidemiologi Kualitas Hidup Penderita Paska Stroke di RSUD Propinsi Nusa Tenggara Barat
}

\author{
Epidemiological Studies Post Stroke Quality of Life \\ in West Nusa Tenggara General Hospital \\ Ilsa Hunaifi ${ }^{1 *}$ dan Pujiarohman ${ }^{2}$ \\ ${ }^{1}$ Departemen Neurologi Fakultas Kedokteran Universitas Mataram \\ ${ }^{2}$ Student Support Center Fakultas Kedokteran Universitas Mataram \\ Jl. Pendidikan No 37 Mataram, NTB, 83125, INDONESIA \\ *Corresponding Author email: ilsahunaifi@unram.ac.id
}

Manuscript received: 11-06-2019. Accepted: 25-06-2019

\begin{abstract}
ABSTRAK
Stroke merupakan penyebab kematian dan kecacatan utama di Indonesia. Angka kecacatan yang tinggi mengakibatkan kualitas hidup penderita menjadi buruk dibandingkan dengan populasi normal. Untuk menilai kualitas hidup pasien paska stroke, ditentukan dengan menilai 4 dimensi yakni fisik, fungsional, psikologis dan kesehatan sosial. Di Indonesia, studi-studi terkait kualitas hidup penderita paska stroke belum banyak ditemukan sehingga diperlukan studi untuk mengetahui bagaimana kualitas hidup penderita paska stroke terutama di Nusa Tenggara Barat. Penelitian ini bertujuan untuk mengetahui epidemiologi kualitas hidup penderita paska stroke di Nusa Tenggara Barat. Metode penelitian berupa Observasional dengan desain potong lintang dengan populasi penelitian pada penderita paska stroke di RSUP NTB. Kualitas hidup pasien paska stroke dinilai dengan kuisioner SSQOL (Stroke Specific Quality of Life). Data yang terkumpul dianalisis dengan uji yang sesuai. Hasil penelitian adalah rerata umur subyek penelitian adalah $60.33 \pm 10.68$ tahun. Hipertensi merupakan faktor risiko utama stroke. Nilai rata-rata skor SSQOL sebesar 177.02 \pm 45.75 . SSQOL menilai 4 dimensi yakni dimensi fisik, fungsional, psikologis dan kesehatan sosial. Berdasarkan dimensi fisik didapatkan nilai rerata sebesar 17.00, dimensi fungsional didapatkan nilai rerata sebesar 14.91, dimensi psikologis didapatkan nilai rerata 13.17 dan dimensi kesehatan sosial didapatkan nilai rerata 13.44. Kualitas Hidup penderita paska stroke di RSUD Propinsi NTB cukup baik
\end{abstract}

Kata kunci: Disabilitas; Fungsional; Kesehatan Sosial; Psikologis

\section{ABSTRACT}

Stroke is a leading cause of mortality and morbidity in Indonesia. Post stroke patients has a higher disability hence results in poor quality of life compared with normal population. In 
Indonesia, studies related to the quality of life of post-stroke patients are scarce, so studies are required to explore the quality of life of post-stroke patients, particularly in West Nusa Tenggara. Aim of this study is to determine the epidemiology of quality of life for post-stroke patients in West Nusa Tenggara. Methods of this study is An Observational with cross-sectional design was performed in population of post-stroke patients admitted to West Nusa Tenggara General Hospital. The quality of life of post stroke patient was evaluated with SSQOL (Stroke Specific Quality of Life) questionnaire. The collected data was analyzed by the appropriate test. Result of this study is the average age of subject is $60.33 \pm 10.68$ years. Hypertension is a major risk factor of stroke. The average SSQOL score is $177.02 \pm 45.75$. SSQOL assesses 4 dimension are physical, functional, psychological and social health. Based on the physical dimension, the average score is 17.00 , the functional dimension, the average score is 14.91 , the psychological dimension, the average score is 13.17 and the social health dimension the average score is 13.44. The quality of life for post-stroke patients in West Nusa Tenggara General Hospital is good.

Keyword: disability; functional; psychological; social health.

\section{PENDAHULUAN}

Stroke adalah penyebab kematian dan kecacatan utama di Indonesia. Menurut data Riset Kesehatan Dasar (RISKESDAS) Kementerian Kesehatan Republik Indonesia, prevalensi kejadian stroke meningkat dari 8,3 per 1000 penduduk pada tahun 2007 menjadi 12,1 per 1000 penduduk pada tahun 2013 dan angka kematian akibat stroke sekitar 15\% dan tingkat kecacatan mencapai 65\% (Depkes RI, 2013). Selama ini studi epidemiologi pada stroke terfokus pada angka kematian dan kecacatannya bukan pada kualitas hidup penderita paska mengalami stroke.

Angka kecacatan yang tinggi mengakibatkan kualitas hidup penderita menjadi buruk dibandingkan dengan populasi normal. Sebuah laporan penelitian menyebutkan, di Nigeria kualitas hidup penderita paska stroke memburuk dibandingkan populasi sehat. Faktor utama penyebab kualitas yang buruk pada penderita paska stroke adalah faktor emosional. Pada penderita stroke dengan tingkat pendidikan yang tinggi dibandingkan pendidikan rendah lebih baik dikarenakan mereka taat pada pengobatan dan taat pada perawatan. Disamping itu, faktor usia menentukan kualitas hidup paska stroke. Berdasarkan penelitian, pada penderita usia muda, perbaikan strokenya lebih cepat dibandingkan pada usia tua sehingga hal ini menentukan kualitas hidupnya paska mengalami stroke (Gbiri et al, 2012).

Untuk mengetahui kualitas hidup pasien paska stroke dapat dilakukan secara multidimensi. Untuk menilai kualitas hidup pasien paska stroke, ditentukan dengan menilai 4 dimensi yakni fisik, fungsional, psikologis dan kesehatan sosial. Penilaian dimensi fisik dengan melihat gejala-gejala terkait penyakitnya. Penilaian dimensi fungsional meliputi perawatan diri sendiri, mobilitas, kemampuan mengerjakan pekerjaan rumah dan bekerja. Dimensi psikologis meliputi fungsi kognitif dan emosi dan yang terakhir dimensi sosial yakni interaksi dengan keluarga dan lingkungan (Mudaliar et al, 2018).

Studi-studi terkait kualitas hidup penderita paska stroke di Indonesia belum banyak ditemukan. Prevalensi depresi paska stroke dibandingkan dengan depresi pada populasi umum jauh lebih tinggi. Prevalensi depresi paska stroke berkisar 9-60\%, insiden berkisar 23-40\% 
sedangkan berdasarkan data di rumah sakit berkisar 35-53\% dan pada studi komunitas berkisar 9-23\%. Angka kejadian depresinya meningkat seiring dengan peningkatan usia (Yuliana dkk, 2018). Penelitian Adawiyah dan kawan-kawan, mengfokuskan pada penderita stroke iskemik diatas 8 hari perawatan. Penelitian tersebut menunjukkan bahwa tingkat pendidikan berhubungan dengan domain lingkungan dan domain psikologis. Kecacatan fisik berhubungan dengan domain fisik dan lingkungan (Adawiyah dkk, 2014).

Stroke Specific Quality Of Life (SSQOL) Scale merupakan instrument yang mudah digunakan dan cepat. Untuk mengisi instrument ini diperlukan waktu 10-15 menit dengan wawancara, baik langsung maupun melalui telpon. Namun instrument ini memiliki kekurangan yakni kompleksitas (Russell et al, 2011).

Berdasarkan RISKESDAS tahun 2013 di Nusa Tenggara Barat (NTB) jumlah penderita stroke mencapai 8.3 per 1000 penduduk. Angka ini menurun dibandingkan tahun 2007 yang mencapai 12 per 1000 penduduk (Depkes, 2013). Tenaga kesehatan baik di NTB dan daerah lain selama ini menfokuskan penatalaksanaan stroke untuk mencegah kecacatan dan kematian. Paska perawatan, tenaga kesehatan jarang yang memperhatikan kualitas hidup pasien. Di NTB belum ada penelitian-penelitian yang mengeksplorasi bagaimana kualitas hidup pasien paska stroke. Untuk itu diperlukan penelitian untuk mengevaluasi kualitas hidup pasien paska stroke sehingga dapat digunakan untuk pencegahan dan penatalaksanaan yang lebih baik.

\section{BAHAN DAN METODE}

Penelitian ini merupakan penelitian observasional dengan rancangan potong lintang pada penderita paska stroke baik stroke infark maupun perdarahan. Kriteria inklusi berupa penderita paska stroke minimal 3 bulan dan kriteria eksklusi berupa penderita paska stroke yang mengalami gangguan depresi, gangguan mood, gangguan kepribadian, tidak kooperatif saat dilakukan pemeriksaan dan tidak ada keluarga yang mendampingi. Pemeriksaan kualitas hidup paska stroke dinilai dengan melakukan wawancara pada penderita atau keluarga dengan menggunakan kuisioner SSQOL. Penelitian dilakukan selama 10 bulan mulai dari bulan September 2017 hingga bulan Juni 2018 dan diperoleh subyek penelitian sebanyak 48 orang penderita paska stroke baik stroke iskemik dan stroke perdarahan yang memenuhi kriteria inklusi dan eksklusi. Subyek penelitian diambil di poli saraf RSUD Propinsi NTB Metode analisis menggunakan analisa statistik deskriptif.

\section{HASIL DAN PEMBAHASAN}

Rerata umur subyek penelitian adalah $60.33 \pm 10.68$ tahun. Usia pasien termuda adalah 36 tahun dan tertua berusia 89 tahun. Hipertensi merupakan faktor risiko utama baik stroke iskemik maupun stroke perdarahan. Selain itu didapatkan faktor risiko berupa diabetes mellitus, dislipidemia dan lainnya misalnya merokok dan atrial fibrilasi. Adapun data demografi tercantum dalam Tabel 1. 
Tabel 1. Data demografi subyek penelitian

\begin{tabular}{llcc}
\hline Data & Rentang & Jumlah & Prosentase (\%) \\
\hline Usia & $30-39$ & 1 & 2.1 \\
& $40-49$ & 6 & 12.5 \\
& $50-59$ & 13 & 27.1 \\
& $60-69$ & 20 & 41.7 \\
& $70-79$ & 7 & 14.6 \\
\multirow{3}{*}{ Faktor Risiko } & $>80$ & 1 & 2.0 \\
& Hipertensi & 44 & 91.67 \\
& Diabetes melitus & 6 & 12.50 \\
& Dyslipidemia & 4 & 8.33 \\
& Merokok & 2 & 4.16 \\
& Atrial Fibrilasi & & 2.10 \\
\hline
\end{tabular}

Tabel 2 Kualitas hidup penderita paska stroke

\begin{tabular}{lcc}
\hline Domain & Skore & Prosentase (\%) \\
\hline Energi & 9.33 & 62.22 \\
Peran dalam keluarga & 10.25 & 68.33 \\
Bahasa & 19.90 & 79.58 \\
Mobilitas & 19.98 & 66.6 \\
Mood & 18.75 & 75 \\
Kepribadian & 11.44 & 76.25 \\
Merawat diri sendiri & 18.83 & 75.33 \\
Peranan sosial & 16.63 & 66.5 \\
Berfikir & 10.88 & 72.5 \\
Fungsi Ekstremitas Atas & 17.85 & 71.4 \\
Penglihatan & 13.17 & 87.77 \\
Produktivitas & 10.02 & 66.80 \\
\hline
\end{tabular}

Kualitas hidup penderita paska stroke dinilai dengan menggunakan kuisioner SSQOL Berdasarkan hasil wawancara didapatkan hasil sebagai berikut (Tabel 2) :

Energi. Energi menggambarkan adanya fatigue yang dapat terjadi pada pasien paska stroke. Pada data subyek penelitian didapatkan rata-rata skore adalah 9.33 (62.22\%). Hal ini menunjukkan bahwa subyek penelitian mempunyai nilai yang cukup tinggi dan menunjukkan bahwa tingkat fatigue pada subyek penelitian cukup rendah $(>50 \%)$.

Peran dalam Keluarga. Peran dalam keluarga menggambarkan peranan hidup penderita dalam kehidupan sehari-hari paska mengalami stroke. Dari hasil penelitian didapatkan rata-rata skore adalah 10.25 (68.33\%). Hal ini menunjukkan sebagian besar penderita masih mampu melakukan kembali peran dan aktivitas bersama dalam keluarga.

Bahasa. Kemampuan komunikasi paska stroke sangat berperan penting dalam kehidupan sehari-hari misalnya untuk berkomunikasi dengan keluarga, melakukan aktifitas yang terkait pekerjaan dengan menggunakan telepon. Dari hasil penelitian didapatkan rata-rata skore adalah 
$19.90(79.58 \%)$. Hal ini menunjukkan sebagian besar penderita dapat berkomunikasi dengan baik melalui komunikasi verbal.

Mobilitas. Kemampuan mobilisasi sangat berperan penting dalam melakukan aktivitas seharihari seperti berjalan untuk melakukan aktivitas didalam maupun diluar rumah. Dari hasil penelitian didapatkan rata-rata skore adalah 19.98 (66.6\%). Hal ini menunjukkan sebagian besar penderita dapat melakukan mobilisasi baik secara mandiri maupun dibantu oleh anggota keluarga.

Mood. Mood menggambarkan secara umum apakah pasien paska stroke mengalami depresi dengan keadaannya. Deteksi dini adanya depresi sangat penting untuk penanganan lebih awal agar tidak jatuh pada kondisi yang lebih berat. Dari hasil penelitian didapatkan rata-rata skore adalah 18.75 (75\%). Hal ini menunjukkan sebagian besar penderita tidak mengalami depresi dengan keadaan fisik paska stroke dan penerimaan dirinya sangat baik.

Kepribadian. Kepribadian menjadi penilaian yang penting dalam kualitas hidup pasien paska stroke. Perubahan kepribadian dapat berupa irritable (mudah tersinggung). Pada penelitian ini didapatkan rata-rata skore adalah $11.44(76.25 \%)$. Hal ini menunjukkan sebagian besar penderita tidak mengalami gangguan kepribadian setelah mengalami stroke.

Merawat diri sendiri. Kemampuan merawat diri pribadi menunjukkan kemampuan penderita paska stroke dalam melakukan aktivitas pribadi secara mandiri seperti mandi, makan, memakai baju. Pada penelitian ini didapatkan rata-rata skore adalah 18.83 (75.33\%). Hal ini menunjukkan sebagian besar penderita mampu merawat diri pribadi dan dapat melakukan aktivitas pribadi secara mandiri.

Peranan social. Peranan sosial menggambarkan peranan manusia dalam berhubungan dengan manusia lain sebagai makhluk sosial dan melakukan kegiatan diluar rumah. Pada penelitian ini didapatkan rata-rata skore adalah 16.63 (66.5\%). Hal ini menunjukkan sebagian besar penderita mampu kembali melakukan kegiatan-kegiatan diluar rumah dan berhubungan dengan orang lain.

Berfikir. Berfikir menggambarkan kemampuan kognitif pada pasien paska stroke. Pada penelitian ini didapatkan rata-rata skore adalah 10.88 (72.5\%). Hal ini menunjukkan sebagian besar penderita mempunyai kemampuan kognitif yang masih baik setelah mengalami stroke.

Fungsi Ekstremitas atas. Fungsi ekstremitas atas menggambarkan kemampuan penderita menjalani aktivitas sehari-hari yang menggunakan tangan untuk menunjang kemampuan merawat diri. Pada penelitian ini didapatkan rata-rata skore adalah 17.85 (71.4\%). Hal ini menunjukkan sebagian besar penderita mampu melakukan aktivitas sehari-hari dengan menggunakan tangannya.

Penglihatan. Penglihatan menggambarkan kemampuan mata dalam menunjang aktivitas baik didalam maupun diluar rumah. Pada penelitian ini didapatkan rata-rata skore adalah 13.17 $(87.77 \%)$. Hal ini menunjukkan sebagian besar penderita tidak mengalami gangguan penglihatan paska stroke sehingga mampu menunjang aktivitas sehari-hari.

Produktivitas. Produktivitas menggambarkan kemampuan penderita dalam melakukan pekerjaan setelah mengalami stroke. Pada penelitian ini didapatkan rata-rata skore adalah 10.02 (66.80\%). Hal ini menunjukkan sebagian besar penderita dapat bekerja kembali paska mengalami stroke.

Kualitas hidup penderita paska stroke jarang diperhatikan. Penelitian-penelitian banyak dilakukan untuk mengatasi dan mencegah dampak stroke seperti kecacatan dan kematian. Dampak stroke tidak hanya mengenai fisik, namun dampak pada sosial dan psikologis. Dampak non fisik jarang mendapatkan perhatian. Dampak non fisik antara lain depresi, gangguan kognitif, cemas, afasia, dan kemampuan aktivitas sehari-hari (Opara et al, 2010). 
Penilaian kualitas hidup penderita paska stroke dapat dikerjakan dengan berbagai instrument. Salah satu instrument yang dipakai diberbagai negara dan sudah tervalidasi adalah Stroke Specific Quality Of Life Scale (SSQOL). Instrument ini merupakan alat ukur terbaru untuk mengukur kualitas hidup penderita paska stroke. Wawancara dengan penderita stroke terdiri dari 49 items dan 12 domain Alat ukur ini sahih dan sensitive. Keuntungan dari instrument ini adalah dapat dikerjakan hanya dalam waktu 10 sampai 15 menit dengan wawancara kepada pasien langsung, melalui telpon, dan email (Russell et al, 2011).

Masing-masing domain dalam instrument SSQOL mempunyai tujuan dalam penilaian kualitas hidup penderita paska stroke. Dari hasil penelitian secara kuantitatif, setiap domain dari kualiatas hidup yang dinilai pada penderita paska stroke di RSUD Propinsi mempunyai nilai rata-rata $>50 \%$. Hal ini menunjukkan bahwa kualitas hidup penderita paska stroke yang berobat di RSUD Propinsi cukup baik.

Domain energi pada SSQOL menggambarkan adanya fatigue yang dapat terjadi pada pasien paska stroke. Pada penelitian didapatkan fatigue paska stroke didapatkan pada $38 \%$ penderita sedangkan sisanya tidak merasakan mudah terjadi kelelahan setelah mengalami stroke. Fatigue paska stroke terjadi antara $22-77 \%$. Faktor predisposisi terjadinya fatique antara lain lokasi stroke. Tang dan kawan-kawan menemukan stroke pada basal ganglia dan kapsula interna. Studi lain menunjukkan lesi pada Ascending Aorusal System (ARAS) di brainstem dapat mengakibatkan gangguan ringan pada kesadaran dan mengakibatkan fatigue paska stroke akibat terganggunya jaras serotonin di brainstem (Acciarresi et al, 2014).

Pasien paska stroke diharapkan dapat kembali berperan dan beraktivitas dengan keluarga dan tidak menjadi beban bagi keluarganya. Peranan keluarga dalam merawat pasien paska stroke sangatlah penting. Berdasarkan domain peran dalam keluarga, 68,33\% pasien dapat kembali berperan dalam keluarganya. Peranan keluarga atau perawat dalam merawat pasien stroke menentukan dalam pengawasan pengobatan dan perawatan rehabilitasi disabilitas yang ada pada pasien. Perawatan pasien paska stroke beberapa bulan pertama merupakan periode yang dapat mengakibatkan stress keluarga dan perawatnya. Dilaporkan bahwa 3 bulan paska stroke, penderita seringkali mengalami perubahan kognitif, perilaku dan emosional. Komunikasi antara dokter yang merawat dengan perawat atau keluarga sangatlah penting untuk perawatan pasien paska stroke (Tsai et al, 2015).

Bahasa sangat penting dalam kehidupan sehari-hari. Kemampuan bicara sangat menentukan dalam berbagai kegiatan. Ketidakmampuan bicara akan mengakibatkan adanya hendaya dalam berkomunikasi baik dengan anggota keluarga maupun dengan orang lain. adanya hendaya dalam berbahasa mengakibatkan pasien tidak dapat mengungkapkan keluhan sehingga bisa mengakibatkan depresi pada pasien. Pada penelitian di RSUD Propinsi, 79.58\% pasien dapat berbahasa sehingga dapat melakukan aktivitas sehari-hari seperti berbicara, menelpon dan lain-lain. gangguan berbahasa bisa berupa afasia, dyspraksia dan dysartria. Afasia dapat berupa afasia motorik yaknu ketidakmampuan dalam berbahasa dan afasia sensorik berupa ketidakmampuan memahami sesuatu baik perintah maupun pembicaraan. Untuk mengatasi gangguan berbicara dapat dilakukan penilaian terlebih dahulu team yang tergabung dalam rehabilitasi stroke. Kemudian terapis wicara menilai kemampuan bahasa dan komunikasinya. Terapi dapat dilakukan dengan latihan praktis untuk membantu 
komunikasinya dan latihan fisik untuk membantu kekuatan otot-otot yang berperan dalam berbicara (Stroke Association, 2012).

Kemampuan berjalan menentukan seseorang dalam mobilisasi dan bekerja. Dari domain kemampuan dalam mobilisasi, penderita paska stroke yang berobat di RSUD Propinsi 66.59\% dapat melakukan mobilisasi dan $66.80 \%$ dapat bekerja kembali. Fungsi ekstremitas atas merupakan bagian tubuh yang penting dalam melakukan berbagai pekerjaan, merawat diri sendiri dan berbagai aktivitas lain yang menggunakan tangan. Sebagaian besar responden (>70\%) dapat melakukan aktivitas dengan menggunakan ekstremitas atas termasuk merawat dirinya sendiri. Hal ini menunjukkan bahwa kemampuan melakukan aktivitas sehari-hari pada penderita paska stroke adalah baik. Tujuan utama merawat pasien paska stroke terutama orang tua adalah mampu melakukan aktivitas sehari-hari secara mandiri seperti makan, memakai baju dan dapat ke kamar mandi secara mandiri (Pei et al, 2016).

Depresi paska stroke dapat terjadi pada 40\% penderita (Pedroso et al, 2015). Depresi merupakan prediktor yang kuat terjadinya perburukan kualitas hidup pada penderita paska stroke. Tidak adanya depresi paska stroke mengakibatkan penderita mudah kembali melakukan aktivitas sehari-hari dengan cepat dan perbaikan kualitas hidupnya menjadi baik (Buono et al, 2017).

Kualitas hidup penderita paska stroke di RSUD Propinsi yang dinilai dengan SSQOL mempunyai nilai rata-rata sebesar $177.02 \pm 45.76$. Hasil ini menunjukkan bahwa kualitas hidup penderita paska stroke di RSUD Propinsi jauh lebih baik dibandingkan dengan penderita di Negara Pakistan yang berkisar di skala $164.18 \pm 32.30$, di Brazil yang berkisar di skala 139.7 \pm 38.4 dan di Nigeria yang berkisar di skala 156.71 \pm 41.64 . Dukungan keluarga sangat berpengaruh terhadap kualitas hidup penderita paska stroke. Pada penderita yang lebih muda, seringkali mengalami depresi dan kualitas hidupnya dipengaruhi oleh seberapa besar ketergantungan terhadap orang lain, ada tidaknya nyeri dan depresi (Khalid et al, 2016).

Keterbatasan penelitian ini adalah jumlah sampel yang sedikit, wawancara dilakukan pada penderita dan anggota keluarga yang kadang-kadang tidak tinggal satu rumah dengan penderita dan hanya dilakukan penilaian satu kali. Dengan adanya keterbatasan diatas maka penilaian kualitas hidup penderita paska stroke menjadi kurang bermakna dan memerlukan sampel yang lebih banyak untuk dapat menilai kualitas hidup penderita yang sebenarnya.

\section{KESIMPULAN}

Kualitas hidup penderita paska stroke di RSUD Propinsi NTB tergolong baik meskipun diperlukan penilaian berulang kali untuk mengetahui kualitas hidup yang sebenarnya.

\section{DAFTAR PUSTAKA}

Acciarrei M, Bogousslavsky J, Paciaroni M, 2014. Post Stroke Fatigue: Epidemiology, Clinical Characteristics and Treatment, Eur Neurol 72 : 255-261

Adawiyah R, Kariase IM, 2014. Faktor-faktor yang berhubungan dengan kualitas hidup penderita paska stroke. www.lib.iu.ac.id [30 Oktober 2017] 
Buono V, Corallo F, Bramanti P, Marino S. 2017. Coping strategies and health related quality of life after stroke. Journal of Health Psychology 22 (1): 16-28

Departemen Kesehatan Republik Indonesia, 2013. Riset Kesehatan Dasar. www. kemkes.go.id [30 Oktober 2017]

Gbiri CA, Akinpelu AO, 2012. Quality of life of Nigerian stroke survivors during first 12 months post-stroke. Hongkong Physiotherapy Journal 30: 18-24

Khalid W, Rozi S, Ali TS, Azzam I, Mullen MT, Ilyas S et al. 2016. Quality Of Life After stroke in Pakistan, BMC Neurology 16: 250.

Mudaliar MR, Yiragamreddy SR, Tejashwani PP, Umapathi S, Sake N, Sharma S. 2018. Quality of Life in Stroke Patients using SSQOL scale and Bartel Index. Indian Journal of Pharmacy Practice 11: 44-50.

Opara JA, Jaracz K. 2010. Quality of life of post stroke patients and their caregivers, Journal of medicine and life 3 (3): 216-220

Pei L, Zang XY, Wang Y, Chai QW, Wanh JY, Sun CY et al, 2016. Factor associated with activities of daily living among the disabled elder with stroke. International Journal of Nursing Science 3: 29-34

Russell M, Dempster M, Donnely M, 2011. Measuring health-related quality of life after stroke: A brief tool. Applied Research in Quality of Life, 6(1), 41-51

Stroke Association. Communication Problem After Stroke. 2012. www.stroke.org.uk [10 September 2018]

Yuliana T, Tammasse J, Bintang AK. 2018. Efek repetitive transcranial magnetic stimulation pada perbaikan depresi paska stroke iskemik. JST Kesehatan 8(2): 197-205 